\title{
Fermentabilitas Ransum Sapi Perah Berbasis Jerami Padi dan Daun Kaliandra yang Disuplementasi Konsentrat Terfermentasi
}

\author{
Fermentability of Rice Straw and Calliandra Leaves Based-Rations \\ Containing Femented Concentrate
}

\author{
T. Hidayat, S. S. Sudana, U. H. Tanuwiria, \& I. Hernaman* \\ Fakultas Peternakan Universitas Padjadjaran \\ Jalan Raya Bandung - Sumedang KM 21 Sumedang 45363 \\ *Email korespondensi: iman.hernaman@unpad.ac.id
}

\author{
- Diterima: 01 November 2020 • Direvisi: 16 November 2020 • Disetujui: 17 Desember 2020
}

\begin{abstract}
ABSTRAK. Penelitian bertujuan untuk mengetahui fermentabilitas ransum berbasis jerami padi dan kaliandra yang mengandung konsentrat terfermentasi (in vitro). Penelitian dilakukan secara eksperimental dengan rancangan acak lengkap yang terdiri dari 4 perlakuan dan 5 ulangan. Data dilakukan sidik ragam dan uji Duncan. Ransum perlakuan adalah P0 = $39 \%$ jerami padi $+21 \%$ daun Kaliandra $+40 \%$ konsentrat, $\mathrm{P} 1=39 \%$ jerami padi $+21 \%$ daun Kaliandra $+40 \%$ konsentrat fermentasi, $\mathrm{P} 2=44 \%$ jerami padi $+21 \%$ daun Kaliandra $+35 \%$ konsentrat fermentasi, $\mathrm{P} 3=49 \%$ jerami padi $+21 \%$ daun kaliandra $+30 \%$ konsentrat fermentasi. Hasil menunjukan bahwa bakteri dan protozoa rumen menghasilkan populasi yang tidak berbeda nyata, sedangkan konsentrasi asam lemak terbang dan amonia berbeda nyata $(\mathrm{P}<0,05)$. Ransum $\mathrm{P} 1$ menghasilkan konsentransi asam lemak terbang yang nyata $(\mathrm{P}<0,05)$ paling tinggi $(148,80 \mathrm{mM})$ dengan amonia yang paling rendah $(5,53 \mathrm{mM})$. Sementara itu, konsentrasi amonia tertinggi $(\mathrm{P}<0,05)$ diperoleh pada perlakuan $\mathrm{P} 0$ sebesar 7,54 mM, sebaliknya menghasilkan konsnetrasi asam lemak terbang paling rendah. yaitu 5,35 mM. Kesimpulan ransum dengan komposisi 39\% jerami padi, 21\% kaliandra, 40\% menghasilkan fermentabilitas yang terbaik.
\end{abstract}

Kata kunci : Fermentabilitas, jerami padi, Kaliandra, konsentrat terfermentasi, rumen

ABSTRACT. This study aims to evaluate the fermentability of rice straw and Calliandra leaves-based rations supplemented fermented concentrates (in vitro). The research was conducted experimentally with a completely randomized design consisting of 4 treatments and 5 replications. The data were analyzed by variance and Duncan's test. The treatment rations were P0 $=39 \%$ rice straw $+21 \%$ Calliandra leaves $+40 \%$ concentrate, $P 1=39 \%$ rice straw $+21 \%$ Calliandra leaves $+40 \%$ fermented concentrate, $P 2=44 \%$ rice straw $+21 \%$ Calliandra leaves $+35 \%$ fermented concentrate, P3 $=49 \%$ rice straw $+21 \%$ Calliandra leaves $+30 \%$ fermented concentrate. The results showed that the treatment had no significant effect to rumen bacteria and rumen protozoa populations, while the concentrations of volatile fatty acids and ammonia were significantly different $(P<0.05)$. Ration $P 1$ produced the highest $(P<0.05)$ concentration of volatile fatty acids $(148.80 \mathrm{mM})$ with the lowest $(P<0.05)$ ammonia $(5.53 \mathrm{mM})$. Meanwhile, the highest ammonia concentration $(P<0.05)$ was obtained in the P0 treatment of $7.54 \mathrm{mM}$, on the other hand it resulted in the lowest $(P<0.05)$ concentration of volatile fatty acids, namely $5.35 \mathrm{mM}$. Conclusion, that rations with a composition of $39 \%$ rice straw, 21\% Calliandra, $40 \%$ fermented concentrate yield the best fermentability.

Keywords: Calliandra, fermentability, fermented concentrate, rice straw, rumen

\section{PENDAHULUAN}

Ransum sapi perah umumnya terdiri atas hijauan dan konsentrat. Hijauan merupakan sumber serat yang berfungsi sebagai sumber energi dan menjaga keadaan normal rumen serta aktivitas mikroba didalamnya. Ketersediaan hijauan pakan yang berkesinambungan di Indonesia sering menjadi permasalahan, karena sangat dipengaruhi oleh faktor musim. Hal tersebut dikhawatirkan memengaruhi kelangsungan usaha peternakan. Upaya untuk mengurangi ketergantungan tersebut adalah dengan menggunakan bahan pakan alternatif yang ketersediaannya melimpah, murah, dan berkesinambungan. Salah satu bahan pakan alternatif yang potensial sebagai sumber serat adalah jerami padi. Jerami padi memiliki potensi jumlah yang cukup besar sebagai pakan sumber serat, yaitu sebesar 9 juta ton per tahun. 
Jerami padi memiliki kelemahan antara lain kandungan lignoselulosa yang tinggi, kandungan protein kasar (PK) yang rendah (Wachirapakorn et al., 2016), sifat amba yang tinggi dan kurang palatabel (Yanuartono et al., 2017). Guna mengatasi kekurangan nutrien jerami padi, biasanya peternak menambahkan hijauan lain yang memiliki kualitas yang lebih baik seperti kaliandra (Calliandra callothyrsus).

Daun kaliandra memiliki protein tinggi dan mudah tumbuh. Penggunaan daun kaliandra sebagai pakan perlu dibatasi karena mengandung senyawa tannin (Mufid dan Sutoyo, 2019) yang menghambat penggunaan protein (Cahyani et al., 2012). Namun tannin juga bermanfaat, jika diberikan dalam jumlah yang tepat dapat mengikat protein (protein by pass) yang menguntungkan bagi ternak ruminansia (Anis et al., 1997). Meskipun kaliandra kaya protein, akan tetapi mengingat sama-sama hijauan yang mengandung serat kasar tinggi, maka relatif sulit dicerna. Oleh karena itu, dibutuhkan pakan tambahan berupa konsentrat. Konsentrat banyak mengandung karbohidrat non struktural berupa pati dan gula yang tinggi yang mudah dicerna dibandingkan serat kasar (Hernaman et al., 2017). Penggunaan konsentrat selain mengandung nutrien yang tinggi biasanya juga digunakan untuk meningkatkan kecernaan. Untuk sapi perah kehadiran karbohidrat non struktural berkaitan erat dengan kadar laktosa susu.

Mahalnya bahan baku pakan menyebabkan konsentrat saat ini banyak disusun dari limbah industri pangan. Pemanfaatan limbah, sebagai komponen konsentrat menimbulkan toksik dari mikroorganisme patogenik selama penyimpanan. Keberadaan senyawa-senyawa ini dalam konsentrat dapat mengakibatkan penurunan daya cerna dan gangguan kesehatan pada ternak yang mengkonsumsinya serta sifat mudah rusak dan tengik pada konsentrat. Kelemahan ini dapat diatasi salah satunya dengan proses fermentasi. Pengolahan fermentasi selain bermanfaat untuk meningkatkan fermentabilitas pakan dalam rumen dan kecernaan dari bahan pakan juga dapat meningkatkan nilai gizi, dan meningkatkan palatabilitas (Roger et al., 2015; Salcedo et al., 2010).
Penelitian ini bertujuan untuk mengevaluasi fermentabilitas ransum berbasis jerami padi dan daun kaliandra yang disuplementasi dengan konsentrat terfementasi dengan metode in vitro.

\section{MATERI DAN METODE}

\section{Ransum Penelitian}

Jerami padi diperoleh dari Jatinangor, Kabupaten Sumedang, sedangkan daun kaliandra (Calliandra calothyrsus) diambil dari hutan/kebun di sekitaran Kecamatan Banjaran, Kabupaten Bandung. Konsentrat yang digunakan adalah konsentrat tanpa dan yang telah dilakukan fermentasi menggunakan bahan yang sama. Ransum perlakuan disusun berdasarkan 100 persen bahan kering. Susunan ransum penelitian dan kandungan nutrien disajikan pada Tabel 1. Ransum tersebut diuji secara in vitro dengan metode Tilley dan Terry (1963).

Uji in vitro dilakukan di Laboratorium Nutrisi Ternak Ruminansia dan Kimia Makanan Ternak Fakultas Peternakan Universitas Padjadjaran. Pelaksanaan in vitro tersebut digunakan untuk menguji fermentabilitas ransum percobaan dengan mengukur populasi bakteri dan protozoa rumen dengan metode Ogimoto dan Imai (1981) serta produk fermentasi yang terbentuk di dalam cairan rumen sapi perah berupa asam lemak terbang dan ammonia dengan prosedur yang telah dijelaskan oleh Wandra et al. (2020).

\section{Pembuatan Konsentrat Terfermentasi}

Konsentrat dibuat dari campuran beberapa bahan seperti mie kering afkir, terigu afkir, dedak padi, molases, mineral, TF Premix, limbah tepung beras, kulit kopi, onggok, urea, ampas kecap, bungkil kacang afkir dan kue kering afkir dari pabrik pakan yang berada di Kabupaten Garut. Kemudian konsentrat tersebut disemprot/ditambahkan dengan air pada tingkat kebasahan 35-40\%, lalu ditimbang sebanyak $2 \mathrm{~kg}$ dan ditambahkan inokulum Saccharomyces cerevisiae 0,23\% dan EM-4 2,31\%. Konsentrat yang sudah jadi dimasukkan ke dalam kantong plastik kedap udara, setelah itu difermentasi selama 3 hari dalam suasana anaerob. 
Fermentabilitas Ransum Sapi Perah Berbasis Jerami Padi dan Daun Kaliandra yang Disuplementasi Konsentrat Terfermentasi (Hidayat dkk.)

\section{Pelaksanaan In Vitro}

Sampel sebanyak $0,5 \mathrm{~g}$ dimasukkan ke dalam tabung fermentor yang telah tersimpan di dalam waterbath suhu $39-40^{\circ} \mathrm{C}$, kemudian ditambahkan larutan Mc Dougall (saliva buatan) sebanyak $40 \mathrm{~mL}$ dan cairan rumen sapi perah sebanyak $10 \mathrm{~mL}$. Kemudian dialirkan gas $\mathrm{CO}_{2}$ ke dalam tabung fermentor agar suasana lebih anaerob. Tabung fermentor ditutup dengan karet berpentil. Tabung fermentor tersebut diinkubasi selama 3 dan 24 jam dan setiap 30 menit dilakukan pengocokkan secara kontinyu. Setelah 3 jam inkubasi, isi tabung fermentor dimasukan di dalam tabung reaksi dan disentrifugasi selama 10 menit. Supernatan yang diperoleh digunakan untuk analisis asam lemak terbang dan ammonia. Sampel dalam tabung fermentor yang diinkubasi selama 24 jam, kemudian disaring menggunakan kain muslin dan cairan yang telah disaring diukur jumlah total bakteri dan protozoa di bawah mikroskop.

\section{Pengukuran Total Bakteri}

Cairan rumen hasil penyaringan sebanyak 0,5 $\mathrm{mL}$ dicampurkan dengan larutan formalsaline $10 \%$ sebanyak $4,5 \mathrm{~mL}$. Campuran tersebut diencerkan hingga $10^{-4}$ dan diambil dengan pipet untuk diteteskan pada bagian tengah counting chamber sebanyak 1 tetes yang sebelumnya telah ditutup dengan cover glass. Kemudian dilakukan pengamatan dan perhitungan di bawah mikroskop pada pembesaran 1000 kali. Perhitungan total bakteri dilakukan pada kotak kecil dalam counting chamber. Perhitungan total bakteri dalam $1 \mathrm{~mL}$ cairan rumen adalah:

$$
\begin{aligned}
\text { Total Bakteri } & =\mathrm{b} \times 1 / \mathrm{FP} \times 1 / \text { volume } \\
& =\mathrm{b} \times 10^{4} \times 10^{9} \\
& =\mathrm{b} \times 10^{9} \text { sel bakteri }
\end{aligned}
$$

Keterangan: $\mathrm{FP}=$ Faktor pengenceran

\section{Pengukuran Total Protozoa}

Larutan methylgreen formaldehide saline (MFS) sebanyak 4,5 mL dicampurkan dengan $0,5 \mathrm{~mL}$ cairan rumen yang telah disaring. Cairan ini didiamkan selama 30 menit agar terjadi pewarnaan pada nukleus. Setelah itu dilakukan pengamatan di bawah mikroskop pada pembesaran 400 kali. Untuk menghitung jumlah protozoa dalam $1 \mathrm{~mL}$ cairan rumen adalah:

$$
\begin{aligned}
\text { Total Protozoa: } & \mathrm{p} \times 1 / \mathrm{FP} \times 1 / \text { Volume } \\
& =\mathrm{p} \times 10^{1} \times 10^{4} \\
& =\mathrm{p} \times 10^{5} \mathrm{sel} \text { protozoa }
\end{aligned}
$$

\section{Pengukuran Ammonia Cairan Rumen}

Supernatan sebanyak $1 \mathrm{~mL}$ dimasukkan ke bagian kiri sekat cawan Conway, lalu dimasukkan pula $\mathrm{NaOH}$ sebanyak $1 \mathrm{~mL}$ dan ditempatkan di sebelah kanan cawan Conway. Bagian tengah cawan Conway diisi dengan asam borat berindikator merah metil dan brom kresol hijau sebanyak $1 \mathrm{~mL}$. Cawan Conway ditutup dengan penutup yang telah diolesi vaselin untuk menghindari udara masuk. Cawan tersebut digoyang berkali-kali agar terjadi pencampuran antara supernatan dengan larutan $\mathrm{NaOH}$. Cawan disimpan pada suhu kamar selama 24 jam. Setelah 24 jam dilakukan titrasi dengan $\mathrm{H}_{2} \mathrm{SO}_{4} 0,005 \mathrm{~N}$ sampai terjadi perubahan warna menjadi kemerah-merahan. Perhitungan ammonia menggunakan rumus:

$$
\text { Ammonia } \begin{aligned}
\left(\mathrm{N}^{-\mathrm{NH}_{3}}\right)= & \underset{1000}{(\mathrm{~mL}}) \mathrm{mM}
\end{aligned}
$$

\section{Pengukuran Asam Lemak Terbang Cairan Rumen}

Seperangkat alat destilasi uap Markham digunakan untuk mengukur asam lemak terbang. Supernatan sebanyak $5 \mathrm{~mL}$ dimasukkan ke dalam tabung destilasi uap, lalu dipanaskan dengan uap air. Tabung diisi dengan $1 \mathrm{~mL} \mathrm{H}_{2} \mathrm{SO}_{4} 15 \%$ dan ditutup rapat. Asam lemak terbang yang terbawa uap air akan melewati tabung pendingin dan mengalami proses kondensasi, lalu ditampung pada tabung Erlenmeyer yang berisi larutan $5 \mathrm{~mL} \mathrm{NaOH}$ 0,5 N. Kemudian dibiarkan sampai mencapai volume tabung sebanyak $\pm 300 \mathrm{ml}$. Ke dalam tabung Erlenmeyer tersebut ditambahkan larutan phenolptalein sebanyak 2 tetes, lalu dilakukan titrasi dengan larutan $\mathrm{HCl}$ 0,5 N sampai perubahan warna dari merah menjadi bening. Untuk blanko dilakukan tritasi pada

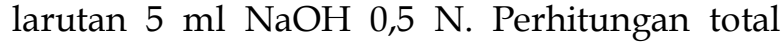
asam lemak terbang menggunakan rumus:

Total asam lemak terbang $=(b-s) \times \mathrm{N} \mathrm{HCl} \times$ $1000 / 5 \mathrm{mM}$ 
Keterangan: $\mathrm{b}=$ vol. titran blanko, $\mathrm{N}=$ normalitas larutan $\mathrm{HCl}, \mathrm{s}=$ vol. titran sampel.

\section{Analisis Statistik}

Penenelitian dilakukan di Laboratorium secara eksperimental menggunakan Rancangan Acak Lengkap (RAL). Data yang dikoleksi, selanjutnya dihitung sidik ragam dan uji Duncan (Steel dan Torrie, 1995).

\section{HASIL DAN PEMBAHASAN}

Kajian in vitro ransum percobaan pada penelitian ini menghasilkan gambaran umum, yaitu populasi bakteri, protozoa, asam lemak terbang dan ammonia dalam cairan rumen sapi perah, yaitu berturut-turut pada kisaran 17,3025,20 $10^{10} \mathrm{sel} / \mathrm{mL} ; 5,00-12,4010^{6} \mathrm{sel} / \mathrm{mL} ; 130,00-$ $148,80 \mathrm{mM}$, dan 5,35-7,54 mM. Populasi bakteri dan protozoa masih dalam kisaran normal karena menurut Muslim et al., (2014) populasi bakteri dan protozoa berkisar $10^{10}$ sampai $10^{11} \mathrm{sel} / \mathrm{mL}$ dan $10^{5}-10^{6} \mathrm{sel} / \mathrm{mL}$. Kondisi ini juga sama dengan produk fermentasi, yaitu asam lemak terbang (130,00-148,80 $\mathrm{mM})$ dan ammonia $(5,35-7,54 \mathrm{mM})$ yang menunjukkan jumlah yang normal pada kisaran 70-150 mM (McDonald et al., 2011) dan 4,45-7,33 mM (Dhia et al., 2019). Kondisi normal ini akan mendukung proses fermentabilitas yang terjadi di dalam cairan rumen. Dengan demikian berdasarkan kajian in vitro tampaknya formulasi ransum yang diujikan memiliki peluang untuk diterapkan, namun demikian untuk mendapatkan ransum yang terbaik dilakukan analisis dengan uji Duncan yang hasilnya disajikan pada Tabel 2 .

Tabel 1. Komposisi bahan pakan dan kandungan zat makanan ransum percobaan

\begin{tabular}{lcccc}
\hline Bahan Pakan & P0 & P1 & P2 & P3 \\
\hline Jerami padi (\%) & 39,00 & 39,00 & 44,00 & 49,00 \\
Kaliandra & 21,00 & 21,00 & 21,00 & 21,00 \\
Konsentrat (\%) & 40,00 & 0,00 & 0,00 & 0,00 \\
Konsentrat terfementasi (\%) & 0,00 & 40,00 & 35,00 & 30,00 \\
\hline Kandungan zat makanan & & & & \\
\hline Abu (\%) & 14,83 & 14,43 & 15,28 & 15,82 \\
Protein kasar (\%) & 12,04 & 12,67 & 12,58 & 12,14 \\
Lemak kasar (\%) & 4,70 & 5,41 & 4,51 & 3,61 \\
Serat kasar (\%) & 21,47 & 20,41 & 21,61 & 22,13 \\
Bahan Ekstrak Tanpa Nitrogen (BETN) (\%) & 46,96 & 47,08 & 46,02 & 46,30 \\
Total Digestible Nutrient (TDN) $)^{*}(\%)$ & 66,80 & 68,50 & 66,55 & 65,16 \\
\hline
\end{tabular}

*) Dihitung berdasarkan rumus Sutardi (2001), yaitu TDN (\%) $=70,6+0,259 \%$ PK $+1,01 \%$ LK- $0,76 \%$ SK+0,0991\%BETN.

Tabel 2. Rataan data fermentabilitas ransum percobaan di dalam cairan rumen

\begin{tabular}{|c|c|c|c|c|}
\hline$\overline{\text { Peubah }}$ & P0 & P1 & P2 & P3 \\
\hline Bakteri $\left(10^{10} \mathrm{sel} / \mathrm{mL}\right)$ & $19,00 \pm 2,76$ & $17,30 \pm 6,29$ & $18,70 \pm 2,39$ & $25,20 \pm 15,53$ \\
\hline Protozoa (106sel/mL) & $11,60 \pm 5,18$ & $8,00 \pm 3,46$ & $11,20 \pm 3,90$ & $12,40 \pm 3,85$ \\
\hline Asam lemak terbang (mM) & $132,70^{a} \pm 2,02$ & $148,80 \_ \pm 5,09$ & $144,40^{\mathrm{b}} \pm 2,61$ & $130,00^{a} \pm 1,64$ \\
\hline Ammonia/N-NH $3(\mathrm{mM})$ & $7,54^{\mathrm{d}} \pm 0,15$ & $5,35 \mathrm{a} \pm 0,17$ & $6,33^{b} \pm 0,09$ & $6,76 \mathrm{c} \pm 0,19$ \\
\hline
\end{tabular}

Keterangan: Superskrip yang berbeda ke arah baris menunjukkan berbeda nyata $(\mathrm{P}<0,05)$.

Setelah dilakukan transformasi data dengan logaritma bagi mikroba rumen, kemudian dilakukan sidik ragam menunjukkan perlakuan tidak nyata memengaruhi populasi bakteri dan protozoa, sedangkan konsentrasi asam lemak terbang dan ammonia memberikan pengaruh yang berbeda nyata $(\mathrm{P}<0,05)$. Ransum P1 menghasilkan konsentrasi asam lemak terbang yang paling tinggi $(\mathrm{P}<0,05)$, yaitu $148,80 \mathrm{mM}$ dengan ammonia yang paling rendah $(\mathrm{P}<0,05)$, sebesar $5,53 \mathrm{mM}$. Sementara itu, kadar ammonia tertinggi $(\mathrm{P}<0,05)$ pada perlakuan P0 sebesar 7,54 $\mathrm{mM}$, tetapi sebaliknya mengandung asam lemak terbang paling rendah $(\mathrm{P}<0,05)$, yaitu $132,70 \mathrm{mM}$. 
Populasi mikroba rumen yang tidak berbeda nyata, diduga karena produk fermentasi berupa asam lemak terbang dan ammonia dalam kondisi normal. Konsentrasi tersebut telah mencukupi untuk perkembangan populasi bakteri dan protozoa. Ammonia mengandung nitrogen yang dibutuhkan dalam pembangunan sel melalui pembentukan protein mikroba (Suryani et al., 2014). Kekurangan pasokan ammonia menyebabkan fermentabilitas dalam rumen terganggu, karena tidak dapat menyokong pertumbuhan mikroba secara maksimum. Asam lemak terbang akan digunakan oleh mikroba rumen sebagai sumber energi dan bersama-sama dengan ammonia membentuk kerangka karbon (Pujowati et al., 2012) dalam menunjang perkembangannya.

Perlakuan P1 menghasilkan konsentrasi asam lemak terbang yang paling tinggi dengan konsentrasi ammonia yang paling rendah. Pada perlakuan P1 menggunakan konsentrat terfermentasi yang paling tinggi (40\%), dimana proses fermentasi merupakan aktivitas mikroba dalam mendegradasi substrat melalui enzim yang dihasilkannya (Hernaman et al., 2017). Pendegradasian substrat menghasilkan senyawa-senyawa yang lebih sederhana, hal ini memudahkan bakteri rumen pencerna serat dan komponen karbohidrat lainnya mudah mengkonversinya menjadi asam lemak terbang. Hal ini diperkuat dengan nilai TDN yang paling tinggi (Tabel 1), dimana nilai tersebut merupakan cerminan mudahnya substrat dicerna. Asam lemak terbang ini akan dimanfaatkan sebagai sumber energi baik untuk mikroba rumen maupun induk semangnya.

Selain karbohidrat, dalam proses fermentasi menyebabkan pula protein konsentrat mengalami penyederhanaan senyawa dan perenggangan ikatannya dengan senyawa lain yang terdapat di dalam bahan pakan. Kondisi ini memungkinkan peluang yang lebih besar bagi tannin yang berada dalam kaliandra untuk mengikat protein, sehingga mengurangi upaya bakteri proteolitik dalam melakukan fermentasi menjadi ammonia. Fenomena ini terjadi juga bagi keseluruhan ransum yang mengandung konsentrat terfermentasi yang menghasilkan konsentrasi ammonia lebih rendah dibandingkan ransum $\mathrm{P0}$ yang mengandung konsentrat yang tidak difermentasi. Tannin merupakan senyawa dalam tumbuhan yang dapat mengikat protein, sehingga sulit untuk dicerna (Ani et al., 2015). Meskipun konsentrasi ammonia rendah, namun memberikan peluang sebagai protein by pass yang dapat memproteksi protein terutama asam amino esensial dari degradasi bakteri rumen. Asam amino esensial dibutuhkan oleh ternak ruminansia terutama yang sedang berproduksi tinggi (Sudekum et al., 2003) seperti sapi perah yang sedang laktasi.

\section{KESIMPULAN}

Penggunaan konsentrat terfermentasi dalam ransum berbasis jerami padi dan kaliandra menyebabkan terjadinya perubahan konsentrasi asam lemak terbang dan ammonia, namun tidak pada populasi bakteri dan protozoa rumen. Komposisi 39\% jerami padi, $21 \%$ kaliandra, $40 \%$ konsentrat terfermentasi (P1) menghasilkan fermentabilitas yang terbaik, hal ini didasarkan pada konsentrasi asam lemak terbang yang paling tinggi dengan ammonia yang paling rendah dan menunjukkan adanya protein by pass.

\section{KONFLIK KEPENTINGAN}

Penulis menyatakan tidak mempunyai konflik kepentingan apapun dalam menulis artikel ini.

\section{UCAPAN TERIMAKASIH}

Penelitian ini menggunakan fasilitas pengujian in vitro milik Laboratorium Nutrisi Ternak Ruminansia dan Kimia Makanan Ternak, Fakultas Peternakan Universitas Padjadjaran, oleh karena itu penulis mengucapkan terima kasih kepada pengelola laboratorium tersebut.

\section{DAFTAR PUSTAKA}

Ani, A. S., R. I. Pujaningsih, \& Widiyanto. 2015. Perlindungan protein menggunakan tanin dan saponin terhadap daya fermentasi rumen dan 
sintesis protein mikrob. Jurnal Veteriner. 16(3): 439-447.

Anis, D. S., K. Charls, \& C. Sumolang. 1997. Penambahan sumber protein by pass pada jerami amoniasi. Laporan Penelitian. Universitas Sam Ratulangi.

Cahyani, R. D., L. K. Nuswantara, \& A. Subrata. 2012. Pengaruh proteksi protein tepung kedelai dengan tannin daun bakau terhadap konsentrasi ammonia, undegraded protein dan protein total secara In Vitro. Animal Agricultural Journal. 1(1): 159-166.

Dhia, K. S., K. A. Kamil, \& U. H. Tanuwiria. 2019. Kecernaan dan fermentabilitas substrat kombinasi mineral- fungi dalam rumen. Jurnal Ilmiah Peternakan Terpadu. 7(2): 217222.

Hernaman, I., A. R. Tarmidi, \& T. Dhalika. 2017. Kecernaan in vitro ransum sapi perah berbasis jerami padi yang mengandung konsentrat yang difermentasi oleh Saccharomyces cerevisiae dan Effective Microorganisms-4 (EM-4). Buletin Peternakan. 41(4): 407-413.

McDonald P., R. A. Edwards, J. F. D. Greenhalgh, \& C. A. Morgan. 2011. Animal Nutrition. $7^{\text {th }}$ ed. Prentice Hall. Englewood Cliffs, New Jersey.

Mufid, Y. \& S. Sutoyo. 2019. Uji aktivitas antioksidan ekstrak methanol daun kaliandra (Calliandra calothyrsus). UNESA Journal of Chemistry. 8(1): $1-4$.

Muslim, G., J. E. Sihombing, S. Fauziah, A. Abrar, \& A. Fariani. 2014. Aktivitas proporsi berbagai cairan rumen dalam mengatasi tannin dengan tehnik in vitro. Jurnal Peternakan Sriwijaya. 3(1): 25-36.

Ogimoto, K. \& S. Imai. 1981. Atlas of Rumen Microbioloby. Japan Societies Press.

Pujowati, A. Sutrisno, \& E. Pangestu. 2012. Kecernaan dan produksi volatile fatty acid pakan komplit yang mengandung tepung kedelai dengan perlakuan pemanasan secara in vitro. Animal Agriculture Journal. 1(2): 151156.

Roger, T., T. N. Léopold, \& M. C. M. Funtong. 2015. Nutritional properties and antinutritional factors of corn paste (Kutukutu) fermented by different strains of lactic acid bacteria. Int. J. Food Sci. http://dx.doi.org/10.1155/ 2015/502910.
Salcedo, G., L. Martinez-Suller, H. Arriaga, \& P. Merino. 2010. Effects of forages supplements on milk production and chemical properties, in vivo digestibility, rumen fermentation and $\mathrm{N}$ excretionin dairy cows offered red clover silage and corn silage or dry ground corn. Irish Journal of Agricultural and Food Research. 49: 115-128.

Steel, R. G. D. \& J. H. Torrie. 1995. Prinsip dan Prosedur Statistika: Suatu Pendekatan Biometrik. Penerjemah: Sumantri, B. Gramedia Pustaka Utama, Jakarta.

Sudekum, K. H., S. Wolffram, P. Ader, \& J. C. Robert. 2004. Bioavailability of three ruminally protected methionine sources in cattle. Anim. Feed Sci. Tech. 113: 17-25.

Suryani N. N., I. K. M. Budiasa, \& I. P. A. Astawa. 2014. Fermentasi rumen dan sintesis protein mikroba kambing Peranakan Ettawa yang diberi pakan dengan komposisi hijauan beragam dan level konsentrat berbeda. Majalah Ilmiah Peternakan. 17(2): 56-60.

Sutardi, T. 2001. Revitalisasi peternakan sapi perah melalui penggunaan ransum berbasis limbah perkebunan dan suplementasi mineral organik. Laporan akhir RUT VIII 1. Kantor Kementerian Negara Riset dan Teknologi dan LIPI.

Tilley, J. M. A. \& R. A. Terry. 1963. A two stage technique for the in vitro digestion of the forage crops. J. Brit. Grassl. Soc. (18)2: 104-106.

Wachirapakorn, C., K. Pilachai, M. Wanapat, P. Pakdee, \& A. Cherdthong. 2016. Effect of ground corn cobs as a fiber source in total mixed diet on feed intake, milk yield and milk composition in tropical lactating crossbred holstein cows. Animal Nutrition. 2: 334-338.

Wandra, F. A., A. K. Pranowo, I. Hernaman, U. H. Tanuwiria, \& B. Ayuningsih. 2020. Fermentabilitas ransum yang mengandung ampas bir dalam cairan rumen (in vitro). Jurnal Sain Peternakan Indonesia. 15 (2): 227136.

Yanuartono, H. Purnamaningsih, S. Indarjulianto, \& A. Nururrozi. 2017. Potensi jerami sebagai pakan ternak ruminansia. Jurnal IlmuIlmuPeternakan. 27(1): 40-62. 